\title{
Ganglioneuroblastoma, Nodular
}

National Cancer Institute

\section{Source}

National Cancer Institute. Ganglioneuroblastoma, Nodular. NCI Thesaurus. Code C42058.

A gang lioneuroblastoma characterized by the presence of neuroblastic cells in a Schwannian stroma, and the formation of hemorrhagic neuroblastic nodules. 